\title{
SENI KOLASE KARYA SISWA KELAS X MIA 2 SMA AL-FITYAN SCHOOL MEDAN DENGAN OBJEK BUAH
}

\author{
Jaka Syahputra $^{1 *}$ Anam Ibrahim²* \\ Program Studi Pendidikan Seni Rupa Jurusan Seni Rupa Fakultas Bahasa dan Seni \\ Universitas Negeri Medan \\ Jl. Willem Iskandar Pasar V Medan Estate, Kec, Percut Sei Tuan, Kab. Deli Serdang, Kode Pos 20371 \\ Sumatera Utara. Indonesia \\ Email:jakasyahputra11@gmail.com, jamurayu@gmail.com
}

\begin{abstract}
Abstrak
Penelitian ini bertujuan Untuk mengetahui tingkat kemampuan sis wa SMA Al-Fityan School Medan dalam menciptakan karya dengan objek buah menggunkan teknik kolase. Metode yang digunakan dalam penelitian ini adalah kualitatif y ang bersifat deskriptif. Objek yang dig ambar untuk berkaryaseni teknik kolase ini adalah buah-buahan yang telah disusun sedemikian rupa untuk kemudian dapat ditiu oleh siswa. Adapun populasi dalam penelitian ini adalah sis wa kelas X Mia SMA Al-Fityan School Medan dengan jumlah 31 sis wa dan sampel yaitu dengan jumlah 3 siswa, dengan menggunakan teknik purposive Sampling. As pek prinsip prinsip seni rupa yang diteliti dalam penelitian ini yaitu bentuk, warna, komposisi dan teknik. Hasil penelitian menunjukan bahwa secara keseluruhan karya seni teknik kolase dengan objek buah-buahan karya siswa X Mia SMA Al-Fityan School Medan dikategorikan baik. Secara keseluruhan aspek bentuk dikategorikan cukup baik, warna memperoleh kategori baik,komposisi memperoleh kategori baik, dan teknik memperoleh kategori baik.
\end{abstract}

Kata Kunci: seni kolase, objek buah.

\begin{abstract}
This study aims to determine the level of ability of students at SMAAl-Fityan SchoolMedan in creating works with fruit objects using collage techniques. The method used in this research is descriptive qualitative. The objects drawn for this collage technique art work are fruits that have been arranged in such a way that students can then imitate them. The population in this study were students of class $X$ Mia SMA Al-Fityan School Medan with a total of 31 students and a sample of 3 students, using purposive sampling technique. Principles of the principles offine arts examined in this study are shape, color, composition and technique. The results showed that overall the collage technique with fruit objects by X Mia SMA Al-Fityan School Medan was categorized as good. Overall, the shape aspect is categorized as quite good, the color is in a good category, the composition is in a good category, and the technique is in a good category.
\end{abstract}

Keywords: collage art, fruit objects.

\section{PENDAHULUAN}

Pendidikan seni budaya merupakan salah satu diantara mata pelajaran yang ada di sekolah SMA (Sekolah Menengah Atas). Mata pelajaran seni budaya merupakan mata pelajaran yang memberikan pengetahuan tentang seni dan keindahan meliputi aktivitas teoritis dan praktis.

Pada materipokok pembelajaran tentang pembuatan karya dengan teknik kolase ini, ada terdapat beberapa karya lukis teknik kolase milik sis wa di SMA Al-Fityan School Medan yang belum maksimal. Hal ini dapat diamati dari beberapa aspek antara lain bentuk yang belum tepat sesuai dengan objek, ada yang terlihat jauh dari bentuk kemiripan dan ada juga yang tidak sebanding antara gambar objek satu dengan gambar objek lainnya, hal ini menagkibatkan bentuknya tidak ideal. Kemudian pemilihan warna yang masih monoton, teknik pemotongan kertas yang tidak rapi, penempelan yang tidak padat dan sembarang, kertas gambar atau alas tidak tertutupi secara merata oleh tempelan dan tidak mempunyai garis tepi.

Pada aspek komposisi terhadap karya siswa tidak seimbang, berat ke kiri dan ada juga berat ke kanan bahkan juga ke atas atau ke bawah. Dalam artian gambarobjeknya terletak condong selain ditengahtengah pada lembaran karya siswa. Pada aspek komposisi ini kebanyakan siswa kurang memperkirakan besar kecilnya objek dan tata letak objek ketika membuat pola pada lembar kerjanya. 
Melihat haldi atas maka perlu dilakukan penelitian lebih jauh lagi.

Berdasarkan dis kusi dan wawancara pada guru seni budaya di SMA Al Fityan School Medan dari kebanyakan beberapa siswa belum terampil dalam menekuni proses berkarya teknik kolase dan karyanya masih sedikit yang dikatakan bagus. Hal ini bisa dis ebabkan oleh beberapa faktor antara lain waktu yang terbatas, tempat yang kurang cocok, kelengkapan bahan tidak terpenuhi, dan peralatan untuk berkarya tidak ters edia maksimal.

Oleh karena itu sebagai tanggung jawab ilmiah maka peneliti ingin mengetahui lebih lanjut tentang perencanaan dan proses pembelajaran sekaligus peneliti ingin meninjau hasil karya sis wa SMA Al fityan School Medan dengan objek gambar buah menggunakan teknik kolase.

\section{KAJIAN TEORI}

\section{Pengertian Kolase}

Kata kolase berasal dari bahasa Prancis yang berati "menempel". Kata kolase yang dalam bahasa Inggris disebut "collage". Menurut Kamus Besar Bahasa Indonesia (KBBI) kolase adalah komposisi artis tik y ang dibuat dari berbagai bahan (dari kain, kertas, kayu,) yang ditempelkan pada permukaan gambar.

Menurut pendapat Nicholson (2007:5) menjelaskan bahwa "kolase adalah gambar yang dibuat dari potongan kertas atau material lain yang ditempelkan. Bahan y ang dapat dimanfaatkan benda apapun untuk membuat kolase, seperti karton, tali, dan perhiasan.

Sedangkan menurut Pamadhi \& Sukardi, dalam Khasanah \& Ichsan (2019) Jurnal ilmiah tumbuh kembang anak usia dini, menjelaskan bahwa kolase adalah karya seni rupa dua dimensi yang menggunakan bahan bermacam-macam selama bahan dasar ters ebut dapat dipadukan dengan bahan dasar lain yang akhirnya dapat menyatu menjadi karya yang utuh dan dapat mewakili ungkapan perasaan estetis orang yang membuatnya.

Dari beberapa pendapat diatas maka dapat disimpulkan bahwa kolase merupakan suatu karya yang dibuat dengan cara menempelkan potonganpotongan kertas, kain, karton atau material lainnya pada media yang sudah ada polanya.

\section{Tujuan dan Manfaat Teknik Kolase 1). Tujuan}

Menurut Mayesky (2004:40) menjelaskan tujuan teknik kolase yaitu mengembangkan kreativitas, mengembangkan motorik kecil, dan koordinasi dengan mata dan mengeks plorasi tekstur-tekstur y ang berbeda dari kertas melalui pembuatan kolase.

Menurut Yohana, (2013:23) adapun dua tujuan dan manfaat kegiatan kolase ini yaitu sebagai berikut: (1) Agar anak mampu mnegerjakan fungsi motorik halus untuk menyusun potongan-potongan bahan (kain, kertas, kayu, dan biji-bijian) dan merekatnya pada pola atau gambar. (2) Anak dapat mempraktikan langsung.

Dari penjelasan di atas maka dapa disimpulkan tujuan pembuatan teknik kolase adalah mengembangkan daya kreativitas dan motorik kecil/halus terhadap sipelakunya.

\section{2). Manfaat}

Adapun manfaat kolase menurut Yohana (2013:23) adalah sebagai berikut: (1) Menstimulus kemampuan motorik halus, (2) Dapat meningkatkan kreativitas anak, (3) Dapat melatih konsentrasi anak, (4) Anak dapat mengenal warna dan menambah kosa kata bagi anak, (5) Anak dapat mengenal bentuk geometri dan yang bukan geometris, (6) Melatih anak untuk mneyelesaikan masalah melalui permainan kolalse, (7) Men gasah kecerdasan spesial anak, (8) Melatih ketekunan pada anak, (9) Meningkatkan percaya diri pada anak.

\section{Bahan dan Alat Membuat Kolase \\ 1). Bahan Membuat Kolase}

Menurut Sholichah (2017:4) bahan dalammembuat kolase adalah sebagai berikut: serutan kayu, kaca, batu, logam, keramik, tempurung kelapa (batok kelapa), bijia-bijian, daun, kuit tumbuhan, kertas .

\section{2). Alat-alat yang Digunakan dalam Membuat Teknik Kolase}

Alat-alat Membuat karya seni kolase yaitu sebagai berkut: alat pemotongan (gunting, carter), peng garis, lem, pensil.

\section{Langkah-Langkah Kerja Membuat Kolase}

Langkah kerja dalam membuat kolase hal penting yang pertama adalah persiapan bahan dan alat, kemudian membuat pola, lalu tahap akhir penyusuan atau penempelan. 


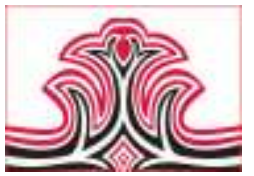

\section{Unsur-Unsur Seni Rupa Dalam Kolase \\ 1). Titik}

Titik adalah citra bentuk paling sederhana. A tau juga dapat dikatakan sebagai unsur bentuk terkcil karena tidak dapat dideteksi batas-batasnya. (Sembiring.2014: 137).

Titik merupakan elemen terkecil dari suatu bentuk. Karakter dari titik dapat dilihat berdasarkan ukurannya yaitu bessar kecilnya suatu titik (Wijaya.2010).

Menurut sanyoto dalam (Febrianto,2014) menyatakan titik adalah unsur seni rupa dua dimensi yang paling dasar. Dari pendapat di atas titik adalah bagian terkecil dari bentuk yang ukurannya sulit dipatokkan.

\section{2). Garis}

Menurut KBBI garis adalah aturan kubu yang dikuasai, daerah pertahanan yang dikuasai, goresan panjang sebagai batas. Garis merupakan kumpulan dari titik dengan jarak yang sangat rapat dan berdekatan (Wijaya. 2010). Sedangkan menurut (Sembiring 2014:138) garis adalah suatu rona rupa yang timbul dari sekali gores an dari alat pewarna. Menurut Rustarmadi (2005 : 19) "Garis adalah semua torehan benda ke bidang taferil yang menghasilkan suatu goresan kasat mata". Dari pendapat di atas garis adalah goresan panjang melebihi titik yang berwujud nyata atau semu.

\section{3). Bidang}

Menurut KBBI bidang merupakan permukaan yang rata dan tentunya. Bidang (shapes) adalah suatu bentuk yang sekelilingnya dibatasi oleh garis, baik garis nyata maupun garis semu. (Sembiring. 139:2014). Menurut Syafei dalam Rus tarmadi dalam (Febrianto,2014) menjelaskan bahwa : "Bidang sering pula disebut 'raut'. Raut adalah tampang, potongan, bentuk suatu objek. Raut sering dipahami atau dikenali sebagai bidang atau bentuk". Dari beberapa penjelasan di atas dapat disimpulkan bidang adalah terdiri dari beberapa garis semu atau nyata yang mengeliling sehingga menjadi bentuk.

\section{4). Bentuk}

Bentuk adalah salah satu dari tujuh unsur seni. Bentuk yang paling mendasar adalah bentuk yang bermatra dua dan tiga dimensi. (Sembiring.2014:136). Menurut wikipedia
Gorga : Jurnal Seni Rupa Volume 09 Nomor 02 Juli-Desember 2020 p-ISSN: 2301-5942 | e-ISSN: 2580-2380

bentuk ialah satu titik temu antara ruang dan massa. Bentuk juga merupakan penjabaran geometris dari bagian semesta bidang yang di tempati oleh objek tersebut, yaitu ditentukan oleh batas-batas terluamya namun tidak terg antung pada lokasi (koordinat) dan orientasi(rotasi)-nya terhadap bidang semesta yang di tempati. Bentuk objek juga tidak tergantung pada sifat-sifat spesifik seperti: warna, isi, dan bahan. Menurut David George Kendall dalam wikipedia bentuk adalah seluruh informasi geometris yang akan tidak berubah ketika parameter lokasi, skala, dan rotasinya diubah. Dari penjelas an di atas maka dapat disimpulkan bentuk adalah segala geometris yang berbentuk dua dan tiga dimensi.

\section{5). Warna}

Menurut KBBI warna adalah kes an yang diperoleh mata dari cahaya yang dipantulkan oleh bendabenda yang dikenainya. Warna adalah gelombang cahaya dengan frekuensi berbeda yang mempengaruhi penglihatan kita. (Sembiring. 2014:141). (Menurut febrianto.2014) warna adalah kesan yang ditimbulkan oleh pantulan cahaya pada mata. Dari penjelasan di atas maka dapar disimpulkan warna adalah gelombang cahaya atau kesan yang ditimbukan oleh pantulan cahaya pada mata yang dapat mempengaruhi penglihatan kita.

\section{6). Komposisi}

Menurut yunitatitisari (2018) Komposisi adalah tata susunan yang menyangkut kes eimbangan, kesatuan, irama, dan keselarasan dalam menggambar suatu objek. Sedangkan menurut wikipedia menyatakan bahwa dalam seni rupa, komposisi adalah penempatan atau aransemen unsur-unsur visual atau 'bahan' dalam karya seni, berbeda dari subyek. Ini juga dapat dianggap sebagai organis asi dari unsur seni menurut prinsip seni rupa. Penilaian pertama pada gambar bentuk adalah komposisi objek gambar, yaitu tata letak benda di tengah-tengah bidang gambar terlihat seimbang atau wajar. (Mesra.2014:83).

\section{METODE PENELITIAN}

Metode penelitian yang digunakan yaitu metode peneltian kualitatif. Teknik pengumpulan datayang digunakan observasi dan dokumentasi. Instrumen peneltian yang digunkan yaitu buku catatan, Lembar Penilaian, dan Kamera. Teknik analisis data yang digunakan yaitu deskriptif kualitatif. 


\section{HASIL DAN PEMBAHASAN}

1.Hasil

1). Karya 1

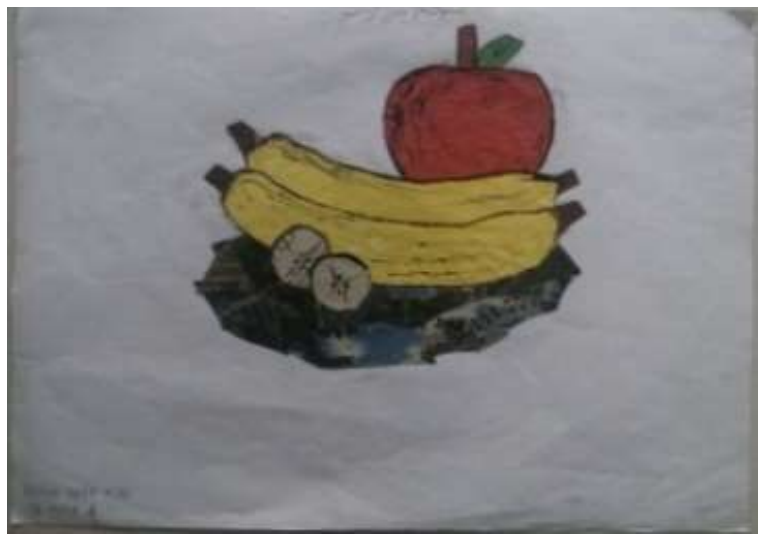

Gambar 1. Karya Almira Syifa Azaila Lubis (Sumber: Jaka Syahputra, 2020)

Tabel 1. Karya Almira Syifa Azalia Lubis

\begin{tabular}{|c|c|c|c|c|c|}
\hline $\begin{array}{l}\text { Indivator } \\
\text { Pesilaian }\end{array}$ & $\begin{array}{c}\text { Apreaizar } \\
\text { I }\end{array}$ & $\begin{array}{c}\text { Apreaiazor } \\
\text { II }\end{array}$ & $\begin{array}{l}\text { Apresiazor } \\
\text { III }\end{array}$ & Fumlas & $\begin{array}{l}\text { Rata- } \\
\text { rata }\end{array}$ \\
\hline Bennik & 76 & 78 & 83 & 237 & 79 \\
\hline Wama & $\overline{100}$ & 92 & 95 & 277 & 93 \\
\hline Koripouili & 75 & 75 & 80 & 230 & 77 \\
\hline Tebrik & 88 & 88 & 88 & 246 & 88 \\
\hline Jumas & & & & & 85 \\
\hline
\end{tabular}

Berdas arkan penilaian yang sudah dilakukan di atas maka diketahui bahwa nilai karya Almira Syifa Azaila Lubis yang menggunakan teknik kolase dengan bahan kertas origami dan kertas koran memiliki nilai yang baik dengan jumlah nilai 337 dan dengan nilairata-rata 85 deng an kategori baik.

\section{2). Karya 2}

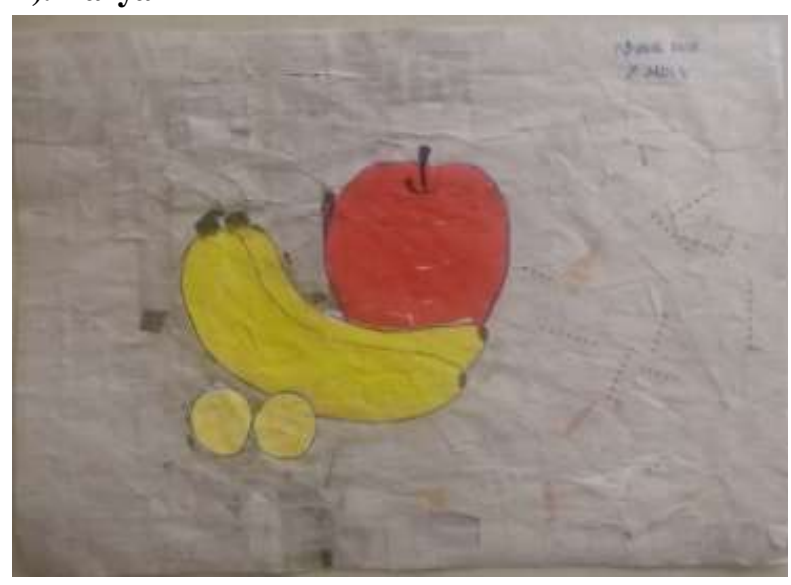

Gambar 2. Karya Nurul Aini

(Sumber: Jaka Syahputra, 2020)
Tabel 2. Karya Nurul Aini

\begin{tabular}{|l|c|c|c|c|c|}
\hline $\begin{array}{c}\text { Indikator } \\
\text { Penilaian }\end{array}$ & $\begin{array}{c}\text { Apresiator } \\
\text { I }\end{array}$ & $\begin{array}{c}\text { Apresiator } \\
\text { II }\end{array}$ & $\begin{array}{c}\text { Apresiator } \\
\text { III }\end{array}$ & Jumlah & $\begin{array}{c}\text { Rata- } \\
\text { rata }\end{array}$ \\
\hline Bentuk & 80 & 80 & 80 & 240 & 80 \\
\hline Wama & 92 & 92 & 92 & 276 & 92 \\
\hline Komposisi & 78 & 78 & 83 & 239 & 80 \\
\hline Telonik & 90 & 88 & 88 & 266 & 89 \\
\hline Jumlah & & & & & 86 \\
\hline
\end{tabular}

Berdas arkan penilaian yang sudah dilakukan di atas maka diketahui bahwa nilai karya Nurul Aini yang menggunakan teknik kolase dengan bahan kertas origami kertas koran memiliki nilai yang baik dengan jumlah nilai 341 dan dengan nilai rata-rata 86 dengan kategori baik.

\section{3). Karya 3}

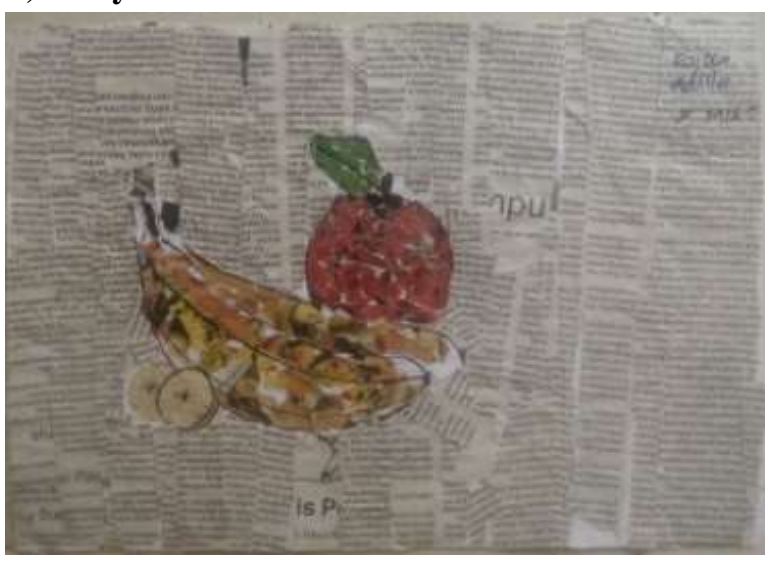

Gambar 3. Karya Raisa Adilla (Sumber: Jaka Syahputra, 2020)

Tabel 3. Karya Raisa Adilla

\begin{tabular}{|l|c|c|c|c|c|}
\hline $\begin{array}{l}\text { Indikator } \\
\text { Penilaian }\end{array}$ & $\begin{array}{c}\text { Apresiator } \\
\text { I }\end{array}$ & $\begin{array}{c}\text { Apresiator } \\
\text { II }\end{array}$ & $\begin{array}{c}\text { Apresiator } \\
\text { III }\end{array}$ & Jumlai & $\begin{array}{c}\text { Rata- } \\
\text { rata }\end{array}$ \\
\hline Bentuk & 76 & 78 & 78 & 232 & 78 \\
\hline Warna & 90 & 92 & 89 & 271 & 91 \\
\hline Kotuposisi & 76 & 78 & 80 & 234 & 78 \\
\hline Teknik & 90 & 88 & 92 & 270 & 90 \\
\hline Jumbah & & & & & 85 \\
\hline
\end{tabular}

Berdas arkan penilaian yang sudah dilakukan diatas maka diketahuibahwa nilaikarya Raisa adilla yang menggunakan teknik kolase dengan bahan kertas origami kertas koran memiliki nilai yang baik dengan jumlah nilai 337 dan dengan nilai rata-rata 85 dengan kategori baik. 
Gorga : Jurnal Seni Rupa

Volume 09 Nomor 02 Juli-Desember 2020

p-ISSN: 2301-5942 | e-ISSN: 2580-2380

\section{Pembahas an}

Penilaian terhadap aspek bentuknya mendapatkan nilai yang cukup baik dengan jumlah nilai 237 dengan nilai rata-rata 79 , namun pada aspek bentukny a mempunyai s edikit ada keku rangan yaitu pada proporsinya. Sedangkan penilaian pada aspek warna karya ini sangat bagus yang menggunakan bahan kertas koran dan kertas origami, warnanya padat, kesannya rapi, dan sedikit bergradasi, dan aspek warna mendapatkan nilai 277 dengan nilai rata rata 93 dengan kategori sangat baik.

Pada as pek komposisi karya ters ebut mendapatkan jumlah nilai 230 kategori cukup baik dengan nilai rata-rata 77, dengan nilai tersebut objek gambamya terletak lebih ke atas. Kemudian pada aspek teknik, karya tersebut sudah menggunakan cara teknik tempel dan pemilihan warna yang ada di koran, namun penempelannya juga padat. kemudian Pada aspek teknik ini mendapakan jumlah nilai 246 dengan nilai rata-rata 88 dikategorikan baik.

Penilaian terhadap aspek bentuknya mendapatkan nilai yang baik dengan jumlah nilai 240 dengan nilai rata-rata 80 , namun pada aspek bentuknya mempunyai sedikit ada kekurangan yaitu bentuk yang kurang proporsional. Sedangkan penilaian pada aspek warna karya ini cukup bagus yang menggunakan bahan kertas origami, namun warnanya sedikit sangat padat tetapi kurang bergradasi, hal berikut aspek warna mendapatkan jumlah nilai 276 dengan nilai rata rata 92 dikategorikan sangat baik.

Pada as pek komposisi karya ters ebut mendapatkan jumlah nilai 239 dan dengan nilai rata-rata 80 dikategorikan baik, dengan nilai tersebut objek gambarnya lebih sedikit ke kanan. Kemudian pada aspek teknik, karya tersebut sudah menggunakan cara teknik tempel, dan penempelan objek buahnya padat dan pada aspek teknik ini mendapakan jumlah nilai 266 dengan nilai rata-rata 89 dikategorikan baik.

Penilaian terhadap aspek bentuknya mendapatkan nilai yang cukup baik dengan jumlah nilai 232 dengan nilai rata-rata 78 , namun pada aspek bentukny a mempunyai s edikit ada kekurangan yaitu bentuk yang kurang proporsional. Sedangkan penilaian pada aspek warna karya ini sangat bagus yang meng gunakan bahan kertas origami dan koran, namun warnanya sedikit kurang, hal berikut aspek warna mendapatkan jumlah nilai 271 dengan nilai rata rata 91 dikategorikan sangat baik.

Pada aspek komposisi karya tersebut mendapatkan jumlah nilai 234 dan dengan nilai rata-rata 78 dikategorikan cukup baik, dengan nilai tersebut objek gambarnya lebih sedikit ke kiri. Kemudian pada aspek teknik, karya tersebut sudah menggunakan cara teknik tempel, dan penempelan objek buahnya cukup padat dan sudah melakukan pemilihan warna sebagai ciri khas teknik kolase. Dan pada as pek teknik ini mendapakan jumlah nilai yang bagus yaitu 270 dengan nilai rata-rata 90 dikategorikan baik.

\section{KESIMPULAN DAN SARAN \\ 1.Kesimpulan}

Indikator ketepatan Bentuk padakarya teknik kolase yang menggunakan objek buah-buahan pada karya 1, karya 2 dan krya 3 rata rata mendapatkan nilai 79 dengan kategori cukup baik. Indikator Warna pada karya teknik kolase yang menggunakan objek buahbuahan pada karya 1, karya 2 dan krya 3 rata rata mendapatkan nilai 92dengan kategori sangat baik. Indikator komposisi pada karya teknik kolase yang menggunakan objek buah-buahan karya padal, karya 2 dan krya 3 rata-rata mendapatkan nilai 78,33 dengan katgori cukup baik. Indikator teknik pada karya teknik kolase yang menggunakan objek buahbuahan pada karya 1, karya 2 dan krya 3 rata rata mendapatkan nilai 89 dengan kategori baik.

\section{Saran}

Dalam menggambar pola siswa harus mampu meng amati ojek yang ada dihad apannya sehingga ia bis a mengetahui dan memahami secara langsung bentuk dan karakteristik objek yang akan digambarnya.

Sis wa harus mampu men genali berbagai media yang digunakan dalamberkarya teknik kolase, mulai dari bahan seperti jenis kertas yang digunakan, hingga lem yang digunakan. Siswa harus mampu menguasai langkah-langkah atau teknik dalam berkarya yang menggunakan teknik kolase.

\section{DAFTAR RUJUKAN}

Febrianto. (2014). Penerapan Media Dalam Bentuk Pop Up Book Pada Pembelajaran Unsur-Unsur Rupa Untuk Sis wa Kelas 2 Sdnu Kanjeng Sepuh Sidayu Gresik. Pendidikan Seni Rupa, 02(3), 146-153.

Kementerian Pendidikan dan Kebudayaan Republik 
Indonesia. (2016-2020). KBBI $V$ 0.4.0

Beta (40). Badan Pengembangan Bahasa

Dan Perbukuan.

Khasanah, Y.N., \& Ichsan. (2019). Meningkatkan

Kreativitas Melalui Kegiatan Kolase pada Anak. Jurnal Ilmiah Tumbuh Kembang Anak Usia Dini, 04(1), 69-84.

Mayesky, Mary. (2004). Aktifitas-Aktifitas Seni

Kreatif Kriya Kertas. Jakarta: Indeks.
Gorga : Jurnal Seni Rupa

Volume 09 Nomor 02 Juli-Desember 2020

p-ISSN: 2301-5942 | e-ISSN: 2580-2380

Wijaya. H (2010). Titik Sebagai Das ar Penciptaan

Karya Seni. Humaniora, 01(2), 253-262.

Yohana, (2013). Tujuan dan manfaatteknik kolase.

Diunduh pada 19 Agustus 2020. [Online].

Dihttps://agroedupolitan.blogspot.com/20

17/02/tujuan-dan-manfaat-teknik-

kolase.html.

Yunitatitisari (2018). apa yang dimaksud dngan komposisi?. Diunduh pada 19 Agustus 2020. Di https://www.dictio.id/t/apa-yangdimaksud-dengan-komposisi/28444.

Bentuk. Diunduh pada 19 Agustus 2020.

[Online].

Di

https://id.wikipedia.org/wiki/Bentuk.

Komposisi (seni rupa). Diunduh pada 19 Agust.

20 Agustus2020. [online]. Di https://id.wikipedia.org/wiki/Komposisi_( seni_rupa) 